\title{
PENGARUH FASILITAS DAN KUALITAS LAYANAN TERHADAP KEPUASAN PELANGGAN KEDAI KOPI BENGKALIS DI PEKANBARU
}

\author{
Oleh: \\ *)SITI SYAHSUDARMI \\ **)Sekolah Tinggi Ilmu Ekonomi Riau (STIE-RIAU)
}

\begin{abstract}
Abstrak
Penelitian ini bertujuan untuk mengetahui pengaruh fasilitas dan kualitas layanan terhadap kepuasan pelanggan pada kedai kopi Bengkalis di Pekanbaru. Instrumen penelitian yang digunakan adalah dengan menyebarkan kuesioner kepada 30 orang pelanggan yang ditentukan dengan menggunakan teknik purposive sampling, peneilitian ini menggunakan metode analisis deskriptif dan verifikatif dengan teknis analisis Partial Least Square (PLS).

Data diklasifikasi berdasarkan variabel yang dijadikan model penelitian. Kemudian diukur factor loading (konvergen validitas), diskriminan validitas, reliabilitas, koefisien determinasi, serta koefisien path dengan menggunakan SmartPLS.

Hasil dari penelitian ini menunjukkan bahwa variabel fasilitas dan kualitas layanan berpengaruh signifikan terhadap kepuasan pelanggan kedai kopi Bengkalis di Pekanbaru. Sedangkan faktor yang berpengaruh paling dominan terhadap kepuasan pelanggan adalah dimensi fasilitas.
\end{abstract}

Kata kunci: fasilitas, kualitas layanan, kepuasan pelanggan.

\section{Pendahuluan}

Persaingan dalam dunia usaha khususnya dibidang kuliner tidak hanya jenis makanan tetapi kuliner jenis minuman sangat bergairah dengan tingkat kompetisi yang cukup tinggi pada saat ini. Tidak hanya rumah makan atau restauran yang menawarkan menu makanan berat secara khusus yang berkembang, akan tetapi kemunculan jenis usaha kedai kopi (coffee shop) yang jualan pokok atau menu utama secara umum menyajikan berbagai jenis minuman, khususnya jenis minuman kopi tumbuh bak jamur dimusim hujan, perkembangannya sangat signifikan saat ini menyebar dibeberapa kota besar maupun kota kecil di Indonesia.

Jenis usaha kedai kopi (juga disebut sebagai warung kopi) pada umumnya diawali dengan konsep atau ide awalnya untuk menyediakan tempat berkumpul atau nongkrong (hangout) sebagai sarana untuk bersosialisasi dengan pokok bahasan yang beragam, mulai dari membicarakan tugas kuliah, pekerjaan, membahas proyek, bisnis sampai topik politik dengan gaya santai dan cenderung informal, yang menyasar dari berbagai segmen pasar, tentunya dengan strategi yang berbeda pada setiap kedai kopi.

Keberadaan kedai kopi juga didukung dengan gaya hidup (life style) millenial kekinian dengan sebutan zaman now baik yang generasi tua (old generation) terutama generasi muda (young generation) baik yang penyuka minum kopi atau yang hanya sekedar menjadikan 
kedai kopi sebagai tempat titik kumpul bersosialisasi dan berdiskusi dengan alasan biaya sangat terjangkau, adanya fasilitas yang cukup memadai dan tersedia akses internet tanpa batas untuk digunakan berselancar kedunia maya tanpa dipungut biaya.

Kedai Kopi Bengkalis yang beralamat di jalan Soekarno Hatta No.9 Pekanbaru berdiri pada tahun 2015 dengan menempati 1 (satu) unit bangunan berbentuk ruko 3 lantai pada awalnya bernama kedai kopi "Arengka Indah", dengan ide awal dan konsep sederhana sebagai tempat minum kopi alternatif yang murah, etnis melayu dan dijamin halal, yang sebelumnya usaha sejenis sudah banyak di kota Pekanbaru yang pada umumnya dimiliki dan dikelola oleh etnis tionghoa selama bertahun-tahun yang lokasinya hanya dibeberapa tempat tertentu diantaranya di jalan Senapelan, jalan Juanda dan jalan Hangtuah,

Ide usaha menyediakan tempat minum kopi alternatif yang digunakan sebagai konsep awal tersebut pada awalnya tidak memiliki identitas yang memiliki makna tertentu yang dapat dijadikan sebagai nilai jual dalam strategi pemasaran dalam menarik pelanggan. Seiring dengan berjalannya waktu, dengan adanya penambahan beberapa fasilitas seperti (1) warna cat interior yang cerah dan senada dengan warna meja kursi; (2) toilet yang bersih; (3) ruang sholat yang nyaman; (4) akses internet gratis (free wifi) dan pelayanan terus dilakukan perbaikan diantaranya (1) menggunakan seragam; (2) cepat tanggap; (3) bersih dan rapi; (4) sopan dan terampil, serta masukan dari pelanggan kedai, maka pada pertengahan tahun 2016 dilakukan perubahan nama usaha menjadi Kedai Kopi Bengkalis. Hal ini dilakukan dengan beberapa alasan yaitu (1) pemilik usaha kedai kopi berasal dari pulau Bengkalis, (2) seluruh karyawan berasal dari bengkalis, (3) menu makanan khas bengkalis.

Perubahan identitas atau merek dagang, penambahan fasilitas yang disediakan dan pelayanan yang terus ditingkatkan menjadi daya tarik baik bagi komunitas kedaerahan yang ingin mencari atmosfir kedaerahan seperti berjumpa kawan lama, berbicara dengan bahasa daerah dan menikmati makanan khas daerah, maupun yang tidak memiliki ikatan kedaerahan yang hanya ingin menikmati makanan khas daerah tertentu saja, perubahan yang dilakukan kedai kopi ini berakibat memberikan dampak terhadap tingkat kunjungan pelanggan kedai kopi seperti yang disajikan pada tabel berikut.

Tabel 1. Tingkat Kunjungan Pelanggan Kedai Kopi Bengkalis di Pekanbaru periode Tahun $2015-2017$.

\begin{tabular}{|c|c|c|}
\hline Tahun & $\begin{array}{c}\text { Jml Pengunjung } \\
\text { (orang) }\end{array}$ & $\begin{array}{c}\text { Perubahan } \\
(\boldsymbol{\%})\end{array}$ \\
\hline 2015 & 10.392 & - \\
\hline
\end{tabular}


Berdasarkan Tabel 1 dapat disimpulkan bahwa tingkat kunjungan pelanggan pada kedai kopi Bengkalis dari tahun 2015 sampai tahun 2017 terus mengalami pertumbuhan, yaitu dari tahun 2015 ke tahun 2016 sebesar 14,85\% atau sebanyak 1.812 pelanggan. Kemudian tahun 2016 ke tahun 2017 masih mengalami peningkatan sebesar 09,30\% atau sebanyak 1.252 pelanggan. Kenaikan jumlah kunjungan pelanggan seharusnya meningkatkan jumlah omset penjualan kedai kopi Bengkalis.

Permasalahan yang terjadi adalah pertumbuhan jumlah pelanggan yang terjadi tidak selaras dengan peningkatan jumlah pendapatan dari omset penjualan kedai Bengkalis seperti yang dapat dilihat pada tabel berikut:

Tabel 2: Tingkat Pendapatan Bruto Kedai Kopi Bengkalis di Pekanbaru periode Tahun 2015 2017.

\begin{tabular}{|c|c|c|}
\hline Tahun & $\begin{array}{c}\text { Pendapatan } \\
\text { (per tahun) }\end{array}$ & $\begin{array}{c}\text { Perubahan } \\
(\mathbf{\%})\end{array}$ \\
\hline 2015 & 369.600 .000 & - \\
\hline 2016 & 455.000 .000 & $19 \%$ \\
\hline 2017 & 410.200 .000 & $(11 \%)$ \\
\hline
\end{tabular}

Sumber: data sekunder 2018

Berdasarkan Tabel 2 di atas dapat disimpulkan bahwa omset penjualan pada tahun 2015 ke 2016 mengalami peningkatan sebesar 19\% atau sebesar Rp 85.400.000. Kemudian dari tahun 2016 ke 2017 mengalami penurunan atau defisit penjualan sebesar Rp 44.800.000 atau (11\%). Terjadinya penurunan omset penjualan kedai kopi Bengkalis di Pekanbaru ini dapat disebabkan oleh beberapa hal yaitu faktor internal dan faktor eksternal. Penyebab dari faktor eksternal diduga karena bertambahnya jumlah pelaku usaha sejenis sehingga market share menjadi berkurang porsinya. Sedangkan penyebab dari faktor internal diduga perlu dilakukan evaluasi secara meyeluruh dan holistik yang terkait dengan pokok bahasan penelitian ini yaitu mengenai fasilitas yang terdapat di kedai kopi, kualitas pelayanan dan penggunaan merek. sehingga pelanggan dapat merasa puas dan melakukan pembelian ulang serta bisa menjadikan pelanggan sebagai relawan duta pemasaran yang efektif bagi kedai kopi Bengkalis.

\section{Tinjauan Pustaka}

\section{Fasilitas}

Pengertian fasilitas menurut Yazid (2005:136) adalah merupakan bagian dari bukti fisik jasa. Disini disebutkan bahwa bukti fisik jasa mencakup seluruh aspek fasilitas fisik 
organisaisi atau the servicescape (mencakup: lingkungan yang diciptakan, buatan manusia, lingkungan fisik jasa). Servicescape berperan sebagai paket dari jasa yang ditawarkan dalam suatu cara yang berbeda dengan cara menawarkan barang. Dengan demikian, servicescape itu merupakan penampilan tangible organisasi dan karena menjadi sangat penting dalam membentuk harapan konsumen. Jasa bersifat intangible, karenanya pelanggan seringkali mengandalkan physical evidence dalam mengevaluasi sebuah jasa sebelum membelinya dan menilai kepuasannya selama dan setelah konsumsi. Menurut Tjiptono (2006:144) fasilitas merupakan bagian dari physical evidence, didalam buku ini dijelaskan secara garis besar, physical evidence meliputi fasilitas fisik organisasi (servicescape) dan bentuk-bentuk komunikasi fisik lainnya.

Menurut Tjiptono (2006:148-149) desain dan tata letak fasilitas jasa erat kaitannya dengan pembentukan presepsi pelanggan. Sejumlah tipe jasa, presepsi yang terbentuk dari interaksi antara pelanggan dengan fasilitas berpengaruh terhadap kualitas jasa tersebut di mata pelanggan. Faktor-faktor yang berpengaruh terhadap fasilitas jasa adalah sebagai berikut:

Pertama, (Sifat dan tujuan organisasi) Sifat suatu jasa seringkali menentukan berbagai persyaratan desainnya. Sebagai contoh desain rumah sakit perlu mempertimbangkan ventilasi yang memadai, ruang peralatan medis yang representatif, ruang tunggu pasien yang nyaman, kamar pasien yang bersih. Desain fasilitas yang baik dapat memberikan manfaat, diantaranya perusahaan mudah dikenali dan desain interior bisa menjadi ciri khas atau petunjuk mengenai sifat jasa didalamnya

Kedua, (Ketersediaan tanah dan kebutuhan akan ruang atau tempat) Setiap perusahaan jasa membutuhkan lokasi fisik untuk mendirikan fasilitas jasanya. Dalam menentukan lokasi fisik diperlukan beberapa faktor yaitu kemampuan finansial, peraturan pemerintah berkaitan dengan kepemilikan tanah dan pembebasan tanah, dan lain-lain.

Ketiga, (Fleksibilitas) Fleksibilitas desain sangat dibutuhkan apabila volume permintaan sering berfluktuasi dan jika spesifikasi jasa cepat berkembang, sehingga resiko keuangan relatif besar. Kedua kondisi ini menyebabkan fasilitas jasa harus dapat disesuaikan dengan kemungkinan perkembangan di masa datang.

Keempat, (Faktor estetis)Fasilitas jasa yang tertata rapi, menarik akan dapat meningkatkan sikap positif pelanggan terhadap suatu jasa, selain itu aspek karyawan terhadap pekerjaan dan motivasi kerjanya juga meningkat. Aspek-aspek yang perlu ditata meliputi 
berbagai aspek. Misalnya tinggi langit-langit bangunan, lokasi jendela dan pintu, bentuk pintu yang beraneka ragam, dan dekorasi interior.

Kelima, (Masyarakat dan lingkungan sekitar) terutama masalah sosial dan lingkungan hidup disekitar fasilitas jasa memainkan peranan penting dan berpengaruh besar terhadap perusahaan. Apabila perusahaan tidak mempertimbangkan faktor ini, maka kelangsungan hidup perusahaan bisa terancam. Kenam, (Biaya kontruksi dan operasi) Kedua jenis biaya ini dipengaruhi desain fasilitas. Biaya kontruksi dipengaruhi oleh jumlah dan jenis bangunan yang digunakan. Biaya operasi dipengaruhi oleh kebutuhan energi ruangan, yang berkaitan dengan perubahan suhu.

\section{Kualitas Layanan}

Kualitas layanan merupakan pemenuhan dari harapan konsumen atau kebutuhan konsumen yang membandingkan antara hasil dengan harapan dan menentukan apakah konsumen sudah menerima layanan yang berkualitas (Goetsch \& Davis dalam Tjiptono dan Chandra, 2011). Kualitas Pelayanan menurut Rambat Lupiyoadi \& A. Hamdani (2008;181) yaitu keberhasilan perusahaan dalam memberikan layanan yang berkualitas kepada para pelanggannya, pencapaian pangsa pasar yang tinggi, serta peningkatan laba perusahaan tersebut sangat ditentukan oleh pendekatan yang digunakan

Kualitas jasa (service quality) dibangun atas adanya perbandingan dua faktor yaitu persepsi pelanggan atas pelayanan yang nyata mereka terima (perceived service) dengan layanan yang sesungguhnya diharapkan/ diinginkan (expected service). Service quality dapat didefinisikan sebagai seberapa jauh perbedaan antara kenyataan dan harapan pelanggan atas layanan yang mereka terima/peroleh.

Terdapat lima dimensi kualitas layanan yang dapat digunakan untuk melakukan evaluasi terhadap kualitas jasa menurut Valerie Zeithaml, A. Parasuraman, dan Leonard Berry (dalam Lupiyoadi, 2006) yaitu:

- Tangible (berwujud), yaitu berupa penampilan fasilitas fisik, peralatan, pegawai, dan material yang dipasang. Dimensi ini menggambarkan wujud secara fisik dan layanan yang akan diterima oleh konsumen. Contohnya dalam jasa restoran, maka karyawannya memakai seragam yang rapi, jumlah meja makan, dan peralatan makan yang lengkap

- Reliability (keandalan), yaitu kemampuan untuk memberikan jasa yang dijanjikan dengan handal dan akurat. Dalam arti luas, keandalan berarti bahwa perusahaan memberikan janjianjinya tentang penyediaan, penyelesaian masalah dan harga. 
- Responsiveness (daya tanggap) yaitu kesadaran dan keinginan untuk membantu pelanggan dan memberikan jasa dengan cepat. Dimensi ini menekankan pada perhatian dan ketepatan ketika berurusan dengan permintaan, pertanyaan, dan keluhan pelanggan.

- Assurance (jaminan) yaitu pengetahuan, sopan santun, dan kemampuan karyawan untuk menimbulkan keyakinan dan kepercayaan. Dimensi ini mungkin akan sangat penting pada jasa layanan yang memerlukan tingkat kepercayaan cukup tinggi dimana pelanggan akan merasa aman dan terjamin.

- Empathy (empati) yaitu kepedulian, dan perhatian secara pribadi yang diberikan kepada pelanggan. Inti dari dimensi empati adalah menunjukkan kepada pelanggan melalui layanan yang diberikan bahwa pelanggan itu spesial, dan kebutuhan mereka dapat dipahami

\section{Kepuasan Pelanggan}

Menurut Mcllroy and Barnett (2000) kepuasan adalah sebuah ukuran seberapa baik harapan pelanggan dipenuhi. Sedangkan menurut Lovelock and Wirtz (2009) kepuasan pelanggan terutama dipusatkan pada keadaan kognitif seseorang, di mana kepuasan pelanggan dipengaruhi oleh kondisi-kondisi suasana hati pada saat pelanggan mengkonsumsi, untuk itu ditemukan bahwa tingkat kesenangan (perasaan hati) akan meningkatkan kepuasan pelanggan.

Menurut Kotler dan Keller (2009, p.164), "Satisfaction reflects a person’s judgements of a product's perceived performance (or outcome) in relationship to expectation" yang berarti kepuasan merupakan perasaan senang atau kecewa yang dihasilkan dari perbandingan performance produk terhadap ekspektasi mereka. Jika performance gagal memenuhi ekspektasi, maka pelanggan menjadi tidak puas. Jika performance sesuai dengan ekspektasi, maka pelanggan menjadi puas. Jika performance melebihi ekspektasi, maka pelanggan merasa sangat puas.

Selanjutnya Engel (Mont et.al, 2003), menyatakan bahwa kepuasan pelanggan diwujudkan dalam bentuk kognitif dan afektif indikator yang digunakan untuk mengukur variabel kepuasan pelanggan, meliputi:

1. Atribut layanan adalah penyampaian layanan yang tepat waktu, akurat dengan perhatian dan keramahan.

2. Garansi layanan adalah ganti rugi yang diberikan sector layanan untuk mengurangi resiko atau kerugian di pihak pelanggan sebelum dan sesudah pembelian atau pemanfaatan pelayanan. 
3. Penanganan keluhan adalah tindakan dalam mengantisipasi agar tidak terjadi kekecewaan pelanggan atau tindakan penyelesaian masalah (keluhan).

Kemudahan dihubungi, sektor pelayanan publik selalu membuka kesempatan kapanpun, menemui siapapun untuk menampung komentar, saran, kritik, pertanyaan maupun keluhan dari pelanggan.

\section{Metode Penelitian}

\section{Rancangan Penelitian}

Penelitian ini bertujuan untuk mengetahui hubungan antar variabel penelitian fasilitas dan kualitas pelayanan terhadap kepuasan pelanggan kedai kopi Bengkalis di Pekanbaru, sehingga penelitian ini termasuk penelitian eksplanatori yaitu suatu penelitian untuk mencari dan menjelaskan hubungan kausal antar variabel melalui pengujian hipotesis.

Penelitian ini menggunakan pendekatan kuantitatif yang bermaksud memberikan penjelasan hubungan kausalitas antar variabel melalui pengujian hipotesis

\section{Populasi dan Pengambilan Sampel}

Populasi dalam penelitian ini adalah semua pelanggan yang melakukan pembelian di kedai kopi Bengkalis di Pekanbaru. Sedangkan Sampel adalah bagian dari populasi yang mempunyai ciri-ciri atau keadaan tertentu yang akan diteliti. Oleh karena itu sampel harus representatif dalam hal besaran, teknik sampling dan karakteristik.

\section{Instrumen Penelitian}

Alat utama dalam penelitian ini adalah kuesioner yang diajukan kepada pelanggan kedai kopi Bengkalis Pekanbaru yang telah ditentukan sebagai sampel dengan ketentuan dan ciri-ciri sebagai berikut:

1. Usia minimal 22 tahun.

2. Pendidikan minimal SMA sederajat.

3. Pelanggan kedai kopi Bengkalis yang sudah berkunjung min. 3 kali.

Dalam kuesioner terdapat sejumlah pertanyaan yang harus di jawab oleh responden sesuai dengan hal-hal yang diketahui, dirasakan dan dialaminya guna memberikan tanggapan yang bebas dan berdasarkan fakta.

\section{Metode Analisis Data}

Metode analisis data menggunakan metode deskriptif dan verifikatif, yaitu hasil penelitian yang kemudian diolah dan diambil kesimpulannya. Dengan menggunakan metode 
penelitian akan diketahui hubungan yang signifikan antara variabel yang diteliti sehingga menghasilkan kesimpulan yang akan memperjelas gambaran mengenai objek yang diteliti.

Metode deskriptif adalah metode yang digunakan untuk menggambarkan atau menganalisis suatu hasil penelitian tetapi tidak digunakan untuk membuat kesimpulan (Sugiyono, 2010).

Sedangkan metode verifikatif adalah pengujian hipotesis penelitian melalui alat analisis (Narimawati, 2008). Analisis verifikatif dalam penelitian ini menggunakan model struktural dengan metode Partial Least Square Path Modeling (PLS-PM). PLS-PM merupakan metode analisis yang powerful karena dapat digunakan pada jenis skala data (nominal, ordinal, interval, dan rasio) (Kurniawan, 2011). Tujuan utamanya adalah untuk menjelaskan hubungan antar konstruk dan menekankan pengertian tentang nilai hubungan tersebut (Gaston dalam Kurniawan, 2011).

Partial Least Square (PLS) mempunyai keunggulan tersendiri (Abdulllah, 2015), diantaranya:

1. Data tidak harus berdistribusi normal multivariate.

2. Ukuran sampel tidak harus besar.

3. PLS tidak saja bisa digunakan untuk mengkonfirmasi teori, tetapi juga dapat digunakan untuk menjelaskan ada atau tidaknya hubungan antara variabel laten.

4. PLS dapat menganalisis sekaligus konstruk yang dibentuk dengan indikator reflektif dan indikator formatif, hal ini tidak mungkin digunakan dalam Struktural Equation Model (SEM) karena akan terjadi unirentifiede model.

\section{Hasil Penelitian}

\section{Analisa Penilaian Outer Model}

Analisa outer model menspesifikasi hubungan antar variabel laten dengan indikatorindikatornya, atau dapat dikatakan bahwa outer model mendefinisikan bagaimana setiap indikator berhubungan dengan variabel latennya. Uji yang dilakukan pada outer model adalah (Hussein, 2015):

a. Uji Validitas dan Reliabilitas

Penilaian outer model dapat dilihat dari hasil uji validitas dan reliabilitas yang dievaluasi dari nilai convergen validity yaitu nilai loading factor $>0,5$ dan nilai Average Variance Extracted $(\mathrm{AVE})>0,5$ atau nilai T-Statistic lebih besar dari T-tabel 1,96 $(\alpha=5 \%)$. 
Uji Reliabilitas dilihat dari composite reliability > 0,7. Nilai batas 0,7 keatas berarti dapat diterima dan diatas 0,8 dan 0,9 berarti sangat memuaskan.

Convergent Validity adalah mengukur validitas indikator refleksif sebagai pengukur variabel yang dapat dilihat dari outer loading dari masing - masing indikator variabel. Suatu indikator dikatakan mempunyai reabilitas yang baik, jika nilai outer loding di atas 0,70 Jonathan Sarwono (2014). Sedangkan nilai outer loading masih dapat ditolerir hingga 0,50 dan dibawah dari nilai 0,50 dapat didrop dari analisis (Ghozali, 2015)

Gambar 2: Outer Loading Variable

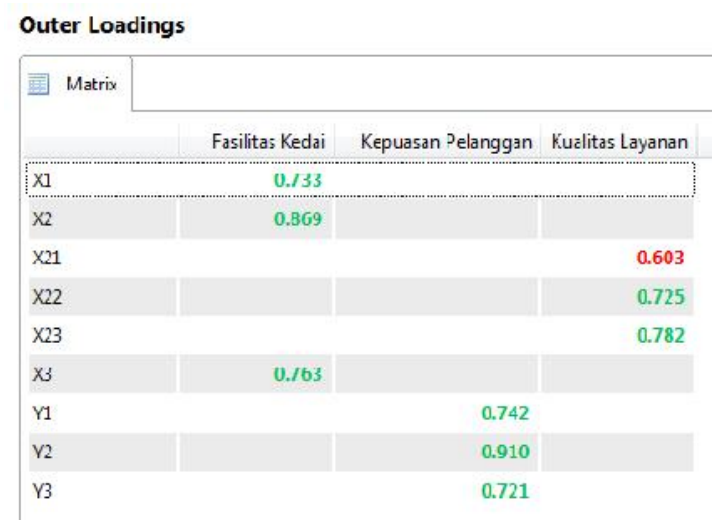

Pada gambar 2 di atas dapat dijelaskan bahwa outer model untuk variabel laten dan indicator yang dijadikan model dalam penelitian ini menunjukkan angka di atas 0,70 sehingga mempunyai reliabilitas yang baik.

\section{Discriminant Validity}

Kriteria pertama untuk Pengukuran discriminant valdity indikator refeleksif dapat dilihat pada cross loading antara indikator dan konstruknya.

\section{Gambar 3: Discriminant Validity}

\begin{tabular}{|c|c|c|c|}
\hline \multicolumn{2}{|c|}{ Fornell-Larcker Criterion } & \multirow{2}{*}{$\begin{array}{l}\text { Cross Loadings } \\
\text { Kepuasan Pelanggan }\end{array}$} & \multirow{2}{*}{$\begin{array}{l}\text { Heterotrait-Mor } \\
\text { Kualitas Layanan }\end{array}$} \\
\hline & Fas litas Kedai & & \\
\hline$x_{1}$ & 0.733 & -0.417 & -0.392 \\
\hline $\mathrm{X} 2$ & 0.869 & -0.473 & -0.462 \\
\hline$X 21$ & -0.293 & 0.123 & 0.603 \\
\hline$x_{22}$ & -0.354 & 0.339 & 0.725 \\
\hline$\times 23$ & -0.247 & 0.403 & 0.782 \\
\hline X3 & 0.763 & -0.415 & -0.081 \\
\hline Y1 & -0.361 & 0.742 & 0.065 \\
\hline $\mathrm{Y} 2$ & -0.573 & 0.910 & 0.608 \\
\hline Y3 & -0.237 & 0.721 & 0.094 \\
\hline
\end{tabular}


Selain uji convergent validity, uji validitas juga dapat dievaluasi dari nilai discriminat validity, yaitu apabila nilai korelasi antar variabel dengan variabel konstruknya memiliki nilai lebih tinggi dibandingkan korelasi variabel dengan variabel konstruk lain.

\section{Analisa Penilaian Inner Model (structural model)}

Analisa inner model atau sruktural model berkaitan dengan pengujian hubungan antar variabel yang sebelumnya dihipotesiskan. Evaluasi inner model dapat dilakukan dengan mengevaluasi nilai koefisien determinasi $\left(\mathrm{R}_{2}\right)$ dan nilai Goodness of Fit $(\mathrm{GoF})$.

a. Koefisien Determinant (R2)

Uji evaluasi terhadap inner model dapat dilakukan dengan melihat nilai koefisien determinasi ( $\left.\mathrm{R}_{2}\right)$ dan nilai Goodness of Fit $(\mathrm{GoF})$.

b. Goodness of Fit (GoF)

Gambar 4: Contruct Reliability and Validity - AVE

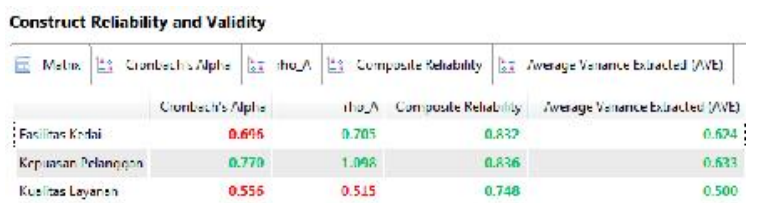

Untuk mencari nilai GoF dapat dicari dengan menggunakan rumus:

$$
\mathrm{GoF}=\sqrt{\overline{\overline{A V E}}} \times \sqrt{\overline{\mathrm{R}^{2}}}
$$

Dengan memasukkan nilai AVE dan R2 pada persamaan di atas, maka diperoleh nilai GoF sebagai berikut:

$$
\begin{aligned}
\text { GoF } & =\sqrt{0,633} \times \sqrt{0,372} \\
& =0,485
\end{aligned}
$$

Nilai GoF ini terbentang antara 0 sampai 1 dengan interpretasi nilai 0,1 (Gof kecil), 0,25 (GoF moderat), dan 0,36 (GoF besar). Nilai GoF semakin besar menunjukkan hasil observasi yang dilakukan sudah sesuai dengan model yang digunakan atau substantial fit/good fit. Berdasarkan nilai GoF sebesar 0,485, maka dapat disimpulkan hasil observasi yang dilakukan sudah sesuai dengan model yang digunakan atau substantial fit/good fit.

\section{Uji Hipotesis}

Dalam penelitian ini terdapat dua hipotesis yang mengukur adanya pengaruh antar variabel. Gambar 5 menjelaskan pengaruh antar variabel aspek fasilitas (facility variablet), kualitas layanan (service quality), terhadap kepuasan pelanggan kedai kopi Bengkalis yang 
dapat dilihat dari hasil bootstrapping dengan nilai t-statistik lebih besar dari 1,96 dan p-value lebih besar dari 0,05, sebagai berikut:

Gambar 5: Path Diagram

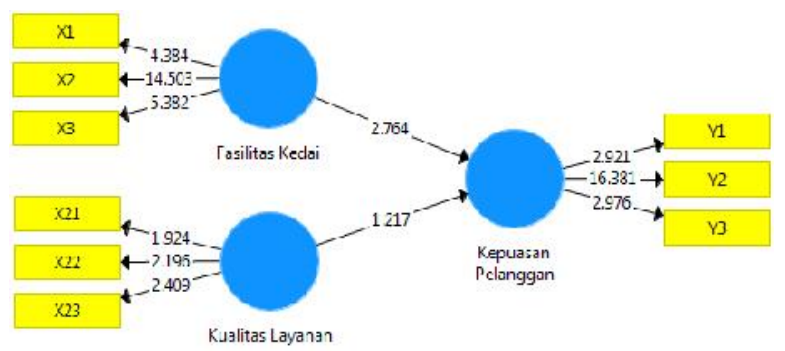

Berdasarkan gambar struktural inner model diatas, dapat disimpulkan pengaruh antar variabel sebagaimana disajikan dalam tabel berikut:

Tabel 3: Path Coefficient

\begin{tabular}{|c|c|c|c|c|c|c|}
\hline \multirow[t]{2}{*}{ (1) Mean, } & \multirow[t]{2}{*}{ Lalues, P-Vyalue } & \multicolumn{2}{|c|}{ c 佂 Confidenc=Intervals } & \multicolumn{3}{|c|}{ 目 Coniidence Intervalk Rias Conre } \\
\hline & & onplc Mson... & Stercourd Devi & viation... & T Statistics ... & PValucs \\
\hline Fasultás Kedá & 0.5950 & 0.582 & & 0.166 & 6.350 & 0.000 \\
\hline Keouasan Pe arcgar & 0.770 & 0.752 & & 0.103 & 7.444 & 0.000 \\
\hline Kualites Leyanan & 0.556 & 0.529 & & 0.155 & 3.594 & 0.000 \\
\hline
\end{tabular}

Sumber: data primer diolah

Berdasarkan tabel 3 di atas dapat diketahui besar koefisien pengaruh dimensi fasilitas terhadap kepuasan pelanggan kedai kopi sebesar 0,696 dengan nilai p-value sebesar 0,000 dengan demikian dapat dikatakan berpengaruh secara positif signifikan. Selanjutnya nilai koefisien pengaruh kualitas layanan terhadap kepuasan pelanggan kedai kopi sebesar 0,556 dengan nilai $p$-value sebesar 0,000 dengan demikian kualitas layanan berpengaruh positif signifikan terhadap kepuasan pelanggan kedai kopi.

\section{Pembahasan}

Didalam penelitian ini terdapat dua hipotesis yang diuji, kedua hipotesis tersebut adalah :

1. Fasilitas yang tersedia di kedai kopi berpengaruh terhadap kepuasan pelanggan kedai kopi Bengkalis.

Hasil penelitian ini mendukung hipotesis pertama bahwa terdapat pengaruh variabel fasilitas terhadap kepuasan pelanggan yang dapat dilihat dari nilai T-statistik yang lebih besar dari T-table sebesar 6,550 sehingga hipotesis dapat diterima.

Hal ini sejalan dengan penelitian yang dilakukan oleh Keukeu Sakibah Nazmi (2014), Gadang Panggegar, dkk (2016), dan Rizal Wahyu Kusuma (2015) yang hasil penelitiannya menyimpulkan bahwa fasilitas memiliki pengaruh signifikan terhadap kepuasan pelanggan. 
Dalam hal ini dimensi fasilitas mencakup fasilitas fisik bangunan, fasilitas parkir, fasilitas ibadah, dan fasilitas akses internet tanpa biaya (gratis).

Fasilitas memiliki beberapa dimensi yang secara umum dikelompokkan menjadi tangible dan intangible facility. Dalam memberikan sentuhan yang memberi kesan nyaman, aman, kebersihan terjamin dan tidak bising menjadi salah satu strategi yang harus terus dipertahankan, agar pelanggan merasakan kenyamanan.

2. Kualitas layanan yang diberikan berpengaruh terhadap kepuasan pelanggan kedai kopi Bengkalis

Hasil penelitian ini mendukung hipotesis kedua bahwa terdapat pengaruh kualitas layanan terhadap kepuasan pelanggan kedai kopi.

Hal ini sejalan dengan penilitian yang dilakukan oleh Vivianli Liu (2016), Barry I.Firmanda (2014), dan Dhien Alfath Aulya (2013) menyatakan bahwa dimensi kualitas layanan memiliki pengaruh signifikan terhadap kepuasan pelanggan.

Dimensi kualitas layanan bersifat dinamis dan strategis, selain mengikuti adab yang bersifat standard, melakukan improvisasi berdasarkan observasi pada pelanggan dalam memberikan pelayanan dapat memberikan kesan lebih dekat secara emosional (personal touch) yang menjadikan pelanggan merasa nyaman dan betah berlama-lama dan melakukan pembelian ulang (repeat order).

\section{Kesimpulan dan Saran}

\section{Kesimpulan}

Berdasarkan hasil analisis yang dilakukan dalam penelitian ini, maka dapat disimpulkan sebagai berikut:

1. Dimensi fasilitas merupakan hal yang sangat fundamental untuk dijadikan saya tarik dalam menerapkan strategi usaha, terutama dalam usaha jasa kuliner selain fasilitas merupakan sampul yang menjadikan penilaian awal yang dapat menimbulkan kesan bagi pelanggan merasa betah untuk berlama-lama singgah dan melakukan kunjungan ulang.

2. Dimensi kualitas layanan yang dijadikan ukuran dalam penelitian ini meliputi kerapian dan kesopanan karyawan, murah senyum dengan tutur kata yang baik dalam melayani, serta cepat tanggap dalam menerima dan menyajikan order.

\section{Saran}


Dari kesimpulan di atas dapat ditarik hal-hal yang perlu untuk dilakukan peningkatan dan perbaikan baik dalam dimensi fasilitas terutama pada dimensi kualitas. Adapun saran yang dapat disampaikan berdasarkan penelitian ini adalah:

1. Terus melakukan perawatan dan melengkapi yang masih terdapat kekurangan pada beberapa fasilitas kedai kopi menjadi penting untuk diagendakan, yang selama ini belum dilakukan penjadwalan secara periodic (rutin).

2. Perlu dipertimbangkan untuk menyiapkan sarana untuk konferensi pers mengingat makin seringnya tokoh politik yang mengunjungi kedai kopi Bengkalis.

3. Dalam hal kualitas pelayanan, masukan yang perlu untuk dilakukan perbaikan adalah :

a. Pembagian kerja antara pelayan, tukang masak, tukang kopi, dan kasir yang tidak teratur atau khusus menimbulkan kesan belum professional, sehingga diperlukan orang-orang yang khusus dan ditempatkan sesuai dengan keterampilannya.

b. Perlu ditambah karyawan terutama pada jam padat khususnya yang bertugas menerima dan melayani order pelanggan.

c. Posisi kasir tidak boleh dalam keadaan tidak ada yang menunggu atau kosong terutama pada waktu padat pengunjung.

\section{Daftar Pustaka}

Abdulllah, M. (2015). Metodologi Penelitian Kuantitatif. Yogyakarta: Aswaja Pressindo.

Abdolmohammadi, M.J.(2005). Intellectual Capital Disclousure and Market Capitalization. Jornal of Intellectual Capital. Vol. 6 No. 3. pp.397-416

Ardiana. (2010). Kompetensi SDM UKM dan Pengaruhnya Terhadap KInerja UKM di Surabaya. Jurnal Manajemen dan Kewirausahaan, VOL. 12, No. 1, hlm:42-55.

Hussein, a. S. (2015). Penelitian Bisnis dan Manajemen Menggunakan parial Least Square (PLS) dengan SmartPLS 3.0. Brawijaya: Universitas Brawijaya.

Kotler, Philip \& Keller, Kevin Lanne. 2009. Marketing management. 13th Edition. New Jersey: Prentice Hall.

Sekaran, Uma. (2011). Metode Penelitian untuk Bisnis edisi 4. Buku I. Jakarta: Salemba Empat

Tjiptono, F. 2005. Pemasaran Jasa. Edisi Pertama. Penerbit Bayu Media. Malang.

Tjiptono. F. dan Chandra. 2005. Manajemen Jasa. Penerbit Andi Offset. Yogyakarta. 
Tjiptono. F. 2006. Pemasaran Jasa. Edisi Pertama. Cetakan Kedua, Bayumedia Publisin, Jawa Timur.

Tjiptono. F. 2007. Strategi Pemasaran. Edisi Kedua, Penerbit Andi. Yogyakarta. . . 2008. Pemasaran Jasa. Edisi Pertama. Cetakan Kedua, Bayumedia Publising, Jawa Timur.

Yazid. 2005. Pemasaran Jasa. Edisi Kedua. Cetakan Pertama, Ekononisia, Yogyakarta 